Carvalho, T. P. A.'; Murolo, F. P. A.' Mattiacci, M.'; Ramos, R. N.'; Rodrigues, A. C. ${ }^{2}$

\title{
46 - Ocorrência de estágios larvais de Ancylostoma spp na areia de parques públicos infantis do município de Santos, Baixada Santista
}

1- Acadêmica de Medicina Veterinária da Universidade Monte Serrat, Santos-SP

2- Professor Doutor de Doenças Parasitárias da Universidade Monte Serrat, Santos-SP

A areia de algumas áreas de lazer de vários parques municipais pode constituir uma fonte de transmissão de doenças parasitárias para o homem. Isso determina uma constante preocupaçào relativa à saúde pública, devido à presença contínua de crianças nestes locais, as quais entram em contato direto com esta areia passível de estar contaminada. Foram analisadas amostras de areia coletadas no periodo de 20 de março a 17 de abril de 2003 , em seis parques infantis municipais, localizados em Santos, SP, quanto à presença de larvas e ovos de parasitas intestinais. $\mathrm{O}$ objetivo foi analisar a incidência de parasitas considerados zoonoses nestes locais. Foram coletadas ao todo trinta amostras, sendo que cada qual foi processada através das técnicas de Ueno para recuperar larvas, e de centrífugo-flutuaçào para recuperar ovos. Observou-se positividade quanto à presença de estágios larvais de Ancylostoma spp em $66,6 \%$ das amostras, e ovos nào embrionados de Ascaris lumbricoides foram encontrados em $10 \%$ das amostras. Conclui-se que a alta prevalência de larvas de Ancylostoma spp encontrada pode potencialmente determinar a ocorrência de larva migrans cutânea em seres humanos, principalmente em crianças freqüentadoras dos parques analisados. A areia destes locais apresenta, dessa forma, risco iminente de contaminação, constituindo um problema de saúde pública.

\section{7 - Ocorrência de parasitos gastrointestinais em cães (Canis familiaris) em três municípios da Baixada Santista}

Pontes, M. J. S. '; Dias, R. A.'; Pereira, J. C. F.'; Feliz, J. C.'; Rodrigues, A. C.2; Nobiling, A. R. ${ }^{3}$;
1- Acadêmicos de Medicina Veterinária da Universidade Monte Serrat, Santos-SP

2- MV, M.Sc. Ph.D. em Parasitologia Veterinária da Universidade Monte Serrat, Santos-SP

3- MV, M.Sc. da Clinica Veterinária Pintassilgo, Santos-SP

Os animais de companhia, principalmente càes e gatos, possuem hoje um papel importante na estrutura familiar e social, convivem mais estreitamente com as pessoas. Esse contato fez surgir uma maior preocupaçào com relação as possíveis zoonoses transmissiveis aos seres humanos, principalmente às crianças. $\mathrm{A}$ análise das amostras fecais de cães possibilita uma melhor avaliação de quais parasitas intestinais acometem esses animais, para que um melhor controle possa ser implantado e um menor risco da transmissão de zoonoses ocorra. Foram analisadas, 122 amostras fecais de cães domiciliados, nas cidades de Santos, Sào Vicente e Praia Grande, no período entre novembro de 2001, fevereiro à maio de 2002, usando a técnica de WILLIS. Foram observadas $47(38,52 \%)$ amostras positivas para helmintos, distribuídas em infecções simples $37(78,72 \%)$ e infecçòes mistas 10 (21,28\%). Observouse que nas infecções simples, a ocorrência de parasitos foi apresentada em ordem decrescente, pelos seguintes helmintos: Ancylostoma sp (67,57\%\%), Toxocara sp (21,62\%), Dipylidium caninum $(8,11 \%)$ e Tricburis sp $(2,70 \%)$. Já nas infecções mistas, a associação de Anclostoma sp + Trichuris sp (60\%), sendo mais incidente, seguida das de Ancylostoma sp + Toxocara sp (20\%), Angylostoma sp + Dipylidium caninum $(10 \%)$ e Anglostoma sp + Cystoisospora obioensis + Cystoisospora canis $(10 \%)$. De acordo com a faixa etária, observou-se que o número de positivos foi de 0 - 6 meses $(45,45 \%)$; de $7-12$ meses $(61,54 \%)$; de $13-24$ meses $(29,41 \%)$; de $25-36$ meses $(36,84 \%)$ e, acima de 36 meses $(35,48 \%)$, indicando que o gênero Ancylostoma sp foi o mais incidente tanto em infecções únicas como em infecções mistas. Os machos apresentam- 